\title{
Effects of Tree Shelters on the Survival and Growth of Argania spinosa Seedlings in Mediterranean Arid Environment
}

\author{
Chamchelmaarif Defaa, ${ }^{1,2}$ Salwa Elantry, ${ }^{3}$ Sanae Lahlimi El Alami, ${ }^{3}$ Ahmed Achour, \\ Abdelhamid El Mousadik, ${ }^{2}$ and Fouad Msanda ${ }^{2}$ \\ ${ }^{1}$ Direction Régionale des Eaux et Forêts et de la Lutte Contre la Désertification du Sud Ouest-Quartier Administratif, BP 520, \\ 80000 Agadir, Morocco \\ ${ }^{2}$ Laboratoire de Biotechnologie et de Valorisation des Ressources Naturelles, FSA, Université Ibn Zohr, BP 8106, Dakhla, \\ 80060 Agadir, Morocco \\ ${ }^{3}$ Centre de la Recherche Forestière, Avenue Omar Ibn Al Khattab, B.P. 763, Rabat, 10050 Agdal, Morocco
}

Correspondence should be addressed to Chamchelmaarif Defaa; ch.defaa@uiz.ac.ma

Received 29 July 2015; Accepted 18 October 2015

Academic Editor: L. M. Chu

Copyright (C) 2015 Chamchelmaarif Defaa et al. This is an open access article distributed under the Creative Commons Attribution License, which permits unrestricted use, distribution, and reproduction in any medium, provided the original work is properly cited.

\begin{abstract}
The argan tree is endemic species of Morocco. It occupies an area of more than $8700 \mathrm{~km}^{2}$ and plays essential ecological and economical roles. In spite of their value, the argan woodlands are subject to rapid and uncontrolled degradation during the last decades, mainly due to overgrazing and systematic collection of argan nuts. The present study was carried out to investigate the effects of two types of tree shelters on survival and growth of Argania spinosa seedlings planted in the southwest of Morocco in order to improve the results of reforestation programs which usually end by repeated failures. The experiment was conducted in the Mesguina forest for two growing seasons after transplantation in the field. After two years, the use of tree shelters significantly increased tree survival and allowed a gain of $20 \%$. Height growth was positively affected by tree shelters. The use of tree shelters showed no significant decrease in basal diameter. In contrast, the height to diameter ratios of sheltered trees were much higher compared to the control. Thus, the use of the tree shelters could aid the early establishment and growth of Argania spinosa under conditions similar to those of the experiment.
\end{abstract}

\section{Introduction}

The argan forests (Argania spinosa (L.) Skeels) extend over 8700 square kilometers [1]. For centuries, argan tree has shaped the socioeconomic life of the southwestern Morocco, becoming a flagship species for the region and for the country [2]. This space has been declared by UNESCO's Man and the Biosphere (MAB) Programme as biosphere reserve in 1998. The argan tree is the major tree species of Macaronesian formations in a climate characterized by very large occult precipitation [3]. Argan tree is a thermophilic and xerophytic tree species, evolving in warm temperate arid bioclimate (along the coast and in the plains) and in warm temperate semiarid bioclimate (High Atlas and Anti-Atlas), with annual rainfall ranging from $400 \mathrm{~mm}$ in the north (Safi), $250 \mathrm{~mm}$ in the Souss Valley, and $150 \mathrm{~mm}$ in the Anti-Atlas to less than
$100 \mathrm{~mm}$ in the southern areas of desert nature [4]. This tree, which can live up to 250 years [5], provides multiple uses for the local population: its very hard wood and the shell of the fruit are used for heating, the leaves and the pulp of its fruit and the oil cake are a valuable fodder for the flock, its thorny branches are used as fence for agricultural plots, edible oil and cosmetics are derived from its seed, and finally the rich soil of the forest area is a very favorable area for intercropping.

During recent years, the argan tree faces many constraints that result in the weakening and degradation of natural forest ecosystems. The argan forests face, in recent decades, the changes in climate and many anthropozoogenic disturbances that result in a reduction in area and density and inexorably lead to the weakening and deterioration of the natural forest ecosystems. As part of the global forest resources assessment [6], official figures provided by Morocco and relating to 
TABle 1: Physicochemical characteristics of the plot study soil.

\begin{tabular}{lcccccc}
\hline Soil depth $(\mathrm{cm})$ & $\mathrm{C}(\%)$ & $\mathrm{N}(\%)$ & $\mathrm{C} / \mathrm{N}$ & $\mathrm{OM}(\%)$ & $\mathrm{pH}(1: 5)$ & $\mathrm{P}(\mathrm{mg} / \mathrm{kg})$ \\
\hline $0-20$ & 2.12 & 0.85 & 24.89 & 3.66 & 3.17 & 36.17 \\
$20-40$ & 0.32 & 0.08 & 40.62 & 0.56 & 7.36 & 36.25 \\
\hline
\end{tabular}

the degradation of the argan tree show a decrease of $111 \mathrm{~km}^{2}$ of the total area of the argan tree between 1990 and 2005, which corresponds to a decrease of $7.4 \mathrm{~km}^{2} /$ year. On the other hand, the argan forests are in almost total lack of natural regeneration [7].

With the aim of preserving this natural resource and to reverse this decline, the Forest Department opted for assisted regeneration in the late $90 \mathrm{~s}$ and led a large reforestation program. However, successful argan plantations are hard to establish, and many reforestation projects have resulted in repeated failures, depriving local users of a vital space for their flocks for too long periods. Some breeders do not respect the exclosure despite the implementation of a state compensation of $350 \mathrm{Dh} / \mathrm{ha}\left(\$ 3600 / \mathrm{km}^{2}\right)$ in favor of users' associations. Infringement of the exclosure by flocks in these areas is one of the main factors of failure of forest regeneration [8]. Added to that is damage by wild animals (hares, gazelles, and boar) and rodents (Barbary ground squirrel and voles) that multiply significantly in these closed spaces where phytomass quickly becomes very important. Under these conditions, individual protection of young seedlings, using tree shelters, is required. Being developed to protect trees from animal damage, these plastic tubes showed their ability to improve early growth by creating a "greenhouse effect" around each tree [9]. Numerous scientific publications have been devoted to the use of shelters in reforestation for several woody species, highlighting many benefits [9-13] but also some of their disadvantages [14-16]. No work has been devoted to the study of the effect of tree shelters on young argan seedlings in the field conditions. The present work aims to test how these techniques can improve the regeneration of argan tree by assessing the effects of individual protection seedlings on its growth parameters under field conditions for the first two growing seasons after transplantation.

\section{Materials and Methods}

2.1. Study Site. The experimental study was carried out at the Mesguina argan forest $\left(9^{\circ} 23^{\prime} \mathrm{W}, 30^{\circ} 25^{\prime} \mathrm{N}\right.$, elevation $\left.115 \mathrm{~m}\right)$ in southwestern Morocco, $25 \mathrm{~km}$ east of Agadir city. The study site is located in a fenced area and strictly closed to grazing. The climate is Mediterranean with an annual mean rainfall of $232.8 \mathrm{~mm}$. The annual mean temperature is $20.0^{\circ} \mathrm{C}$.

Soil samples were collected with auger at depths of $0-$ $20 \mathrm{~cm}$ and $20-40 \mathrm{~cm}$. These samples were analyzed by standard methods to determine the granulometric and physicochemical characteristics. The soil of the study site is sandy clay, with neutral $\mathrm{pH}$, and poor in organic matter (Table 1).

2.2. Materials. The plantation was established in mid-March 2010. The seeds used in this study had the same origin, and the harvest was carried out in argan forest of Ida $\mathrm{Ou}$
Moumen region. Argan seedlings were grown in the Oulad Teima forest nursery located $20 \mathrm{~km}$ from study area. This nursery produces hundreds of thousands of argan seedlings per year and constitutes the main supplier for the argan tree regeneration programs in the whole region. The seedlings were grown in $500 \mathrm{~cm}^{3}$ and $7 \mathrm{~cm}$ square containers filled with $75-25 \%(\mathrm{v} / \mathrm{v})$ white peat and forest soil and transplanted in the field after 11 months in the nursery. These rigid containers are made of black polypropylene. They have an inverted truncated pyramidal shape with an open base in order to promote root air-pruning. The tree shelter used is a doublewalled light green translucent polypropylene vented tube. Openings at the base of the shelter provide ventilation inside the tube. Two heights of the shelters were tested: $120 \mathrm{~cm}$ and $150 \mathrm{~cm}$.

2.3. Experimental Design and Treatments. A complete randomized block design with three blocks was used. Each block contained 102 argan seedlings: 34 with $120 \mathrm{~cm}$ shelters, 34 with $150 \mathrm{~cm}$ shelters, and 34 argan seedlings as control (without shelters). On the plot, seedlings were planted with a density of 204 seedlings/ha, in cubic holes with dimensions of $0.60 \mathrm{~m} \times 0.60 \mathrm{~m}$ in surface and $0.60 \mathrm{~m}$ in depth. A catchment area of $20 \mathrm{~cm}$ high and $1 \mathrm{~m}$ around the plant was established. The 204 shelters (sizes 120 and $150 \mathrm{~cm}$ ) were then placed around the treated plants and 102 argan seedlings were left as control. Until August, every month a regular watering of $30 \mathrm{~L}$ per plant was provided during the first year. During the second growing season, no watering was provided to plants.

For each plant and throughout the duration of the study, plant height and basal diameter were measured. In addition to measurements at the planting date, two measurements were made during the first year (October 30 and December 26) and one measurement (October 30) was made for the following year, except basal diameter for which the measurement was performed only during the first year. Indeed, during the second year, the development of plants and their ramifications in the shelters did not allow measuring the extent of the basal diameter.

2.4. Statistical Analysis. Quantitative variables (survival, growth height, basal diameter, and height to diameter ratio) were analyzed with repeated measures. During the growing seasons 2010 and 2011, 3 measurements were made. The initial values of each variable measured just after planting were considered as a covariable. An analysis of covariance (ANCOVA) was then conducted.

The comparison of averages was made using Scheffé test calculated at $P<0.05$ [17]. Previously, data had undergone logarithmic transformations to satisfy the assumptions required for the covariance analysis. Data for plants survival had undergone an angular transformation arcsine type of the 


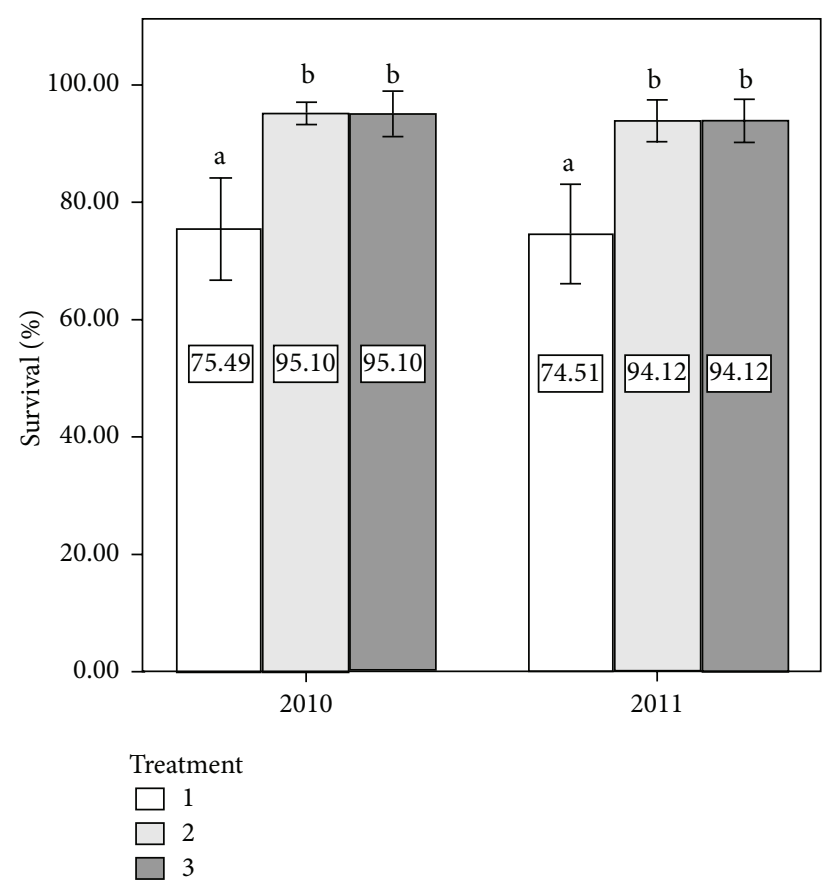

FIgURE 1: Survival rate (\%) of argan seedlings for 2010 and 2011. Treatment 1: control. Treatment 2: seedlings with $120 \mathrm{~cm}$ shelters. Treatment 3: seedlings with $150 \mathrm{~cm}$ shelters. Values sharing the same letter within the same year are not significantly different at $5 \%$ level (Scheffé test).

square $\operatorname{root}\left(Y=2 \operatorname{arsin} X^{1 / 2}\right)$, the raw data being expressed by values from 0 to $1[18]$.

\section{Results and Discussion}

3.1. Survival. After two years of experimentation the results showed that the survival rate was $94.12 \%$ for sheltered trees versus $74.51 \%$ for unsheltered trees. This represents a very high rate that very few regeneration schemes have reached in the region.

Statistical treatments showed highly significant intergroup differences both for the first year $(P=0.0029)$ and for the second year $(P=0.0043)$ for the treatments on survival of argan seedlings. Results showed a positive effect of tree shelters on survival of argan seedlings (Figure 1).

The tree shelters improved significantly the survival rates $(P<0.05)$. The difference with the control was about $20 \%$ in both the first and the second year. Survival rates for seedlings under $120 \mathrm{~cm}$ shelters as well as $150 \mathrm{~cm}$ were not significantly different. After two years, survival rate of $94 \%$ in sheltered plants can be considered exceptional in view of the aridity in this region.

The analysis of Figure 1 shows that annual deaths that occurred in unsheltered seedlings are more important than in sheltered ones. Almost all mortalities were observed during the first year. These results confirm the previous findings $[13,19-24]$ which showed that mortality was higher for unprotected plants compared to sheltered plants. Similar results were found in arid climate for Eucalyptus tree [12].
TABLE 2: Effects of treatments on height growth.

\begin{tabular}{lccc}
\hline Date & Df & $F$ & $P$ \\
\hline October 2010 & 2 & 5.629 & 0.004 \\
December 2010 & 2 & 6.432 & 0.002 \\
October 2011 & 2 & 18.783 & $<0.001$ \\
\hline
\end{tabular}

Df: degree of freedom.

In continental climate, the use of shelters allowed a mean survival gain of $17 \%$ for cottonwood and Siberian elm [25]. Indeed, the shelters played likely a decisive role around the seedlings by creating a favorable microclimate by reducing light intensity [26, 27] and plant transpiration [28] during the summer. According to some studies [29], the soil temperature around unsheltered seedlings may exceed the soil temperature registered in tree shelters by 10 to $20^{\circ} \mathrm{C}$. Moreover, the shelter protected the plants against attack of many mammals in the fenced plot: hares and Barbary ground squirrel (Atlantoxerus getulus) that attacks seedling's shoots and especially its apical part which greatly hinders in growth and causes the death of the plant in case of repeated assaults on young argan trees. Contrastingly, some authors have shown no effect on survival $[16,30,31]$.

Rainfall and temperatures recorded during the two campaigns may explain much of the mortality rates throughout the plot. Thus, the most important mortalities were observed during the first year regardless of the treatment, due to the difficult acclimatization of the argan seedlings. This acclimatization was made all the more difficult by the fact that the field conditions, especially during the 2009/2010 season, have been unfavorable: rainfall has not exceeded $56.2 \mathrm{~mm}$ after the planting date and temperatures were above the annual average. Several heat waves have hit the study area between April and September. These temperatures reached extreme values of $47.3^{\circ} \mathrm{C}$ and $48.3^{\circ} \mathrm{C}$, respectively, on August 12 and August 26, 2010. The shelters gave to the seedlings an additional source of protection from the desiccating wind and thus less evapotranspiration losses. Significant environmental benefits arise due to saved irrigation water by the use of tree shelters in establishing trees in semiarid areas [13]. Thus the use of water and nutrients was better managed and utilized by seedlings that were in the shelter [25].

During the second year, which was very wet, the argan trees found favorable conditions for growth and mortalities greatly diminished. The results are consistent with the findings of studies over several tree species [29, 32]. Moreover, the first year is crucial to overcoming the phenomenon of transplanting stress. This stress is resulting from the confinement of root to the planting hole, poor root-soil contact, and low root permeability [33].

3.2. Height Growth. The statistical treatment showed highly significant effects in the first year and very highly significant effects in the second year on the height growth of argan seedlings (Table 2).

Shelters have significantly stimulated the height growth of argan seedlings compared to the control during the two years of experimentation (Figure 2). 


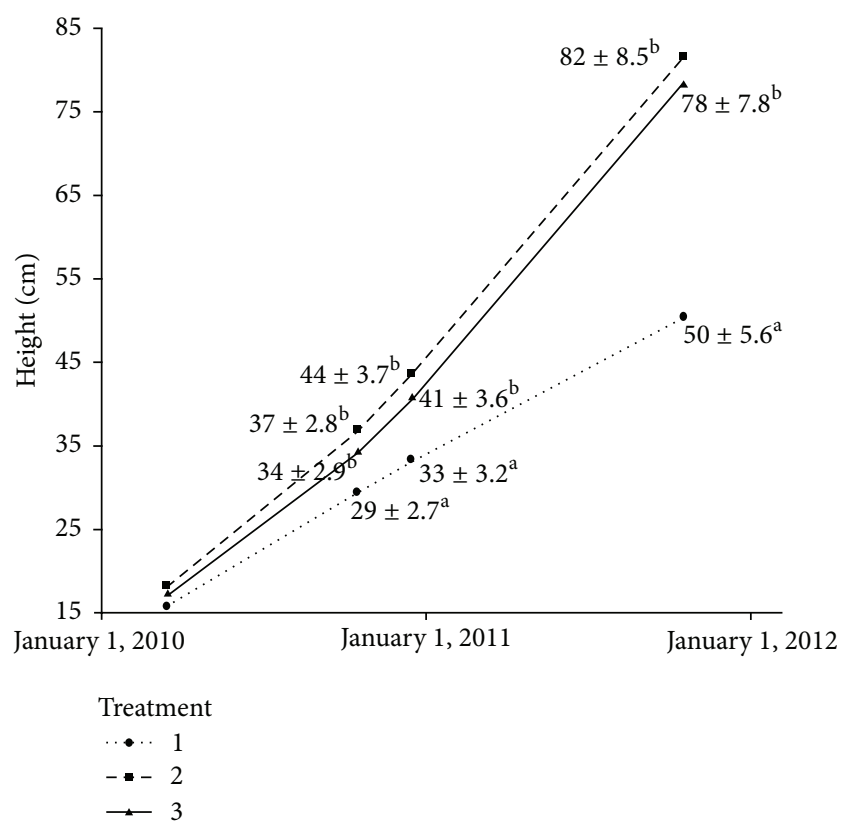

FIGURE 2: Growth height according to tree shelter factor. Treatment 1: control. Treatment 2: seedlings with $120 \mathrm{~cm}$ shelters. Treatment 3: seedlings with $150 \mathrm{~cm}$ shelters. Values sharing the same letter within same date are not significantly different at $5 \%$ by the Scheffé test.

The highest increases were observed for argan seedlings under $120 \mathrm{~cm}$ tubes. There was no significant difference compared to the $150 \mathrm{~cm}$ shelters. These classic effects of stimulation of height growth of seedlings have been reported by many authors for many tree species and climates [19, 20, 23, 24, 26, 34-38]. Similar results were obtained for oak trees in the south of England [9], for walnut in the south of France [14], and for the argan tree after one growing season under nonlimiting water conditions [39]. On the other hand, tree shelter did not improve the height growth of Casuarina cristata and Eucalyptus moluccana [30].

During the first year, the growth rates of sheltered argan seedlings were higher compared to the control. The same trend was observed during the second year when watering was not applied, with much sharper dynamics in sheltered trees. This growth's kinetics were stimulated by favorable water conditions: additional watering during the first year and the exceptional rainfall during the 2nd year.

3.3. Basal Diameter. During the first growing season, the measurements showed that the average of basal diameters had become two times higher than its initial value for all treatments (Figure 3). The greatest diameters were observed for the control, however without significant difference with the sheltered trees.

Thus, for control seedlings, the basal diameter increased from $2.91 \mathrm{~mm}$ at planting date to $6.98 \mathrm{~mm}$ after 9 months, which corresponds to $140 \%$ increase (Figure 4 ). The shelter seedlings had the lowest mean basal diameter. With the exception of publications on two oak species [9] where the tubes allowed good growth of the diameter and the lack of effect on magnolia and oak [34], the results are consistent

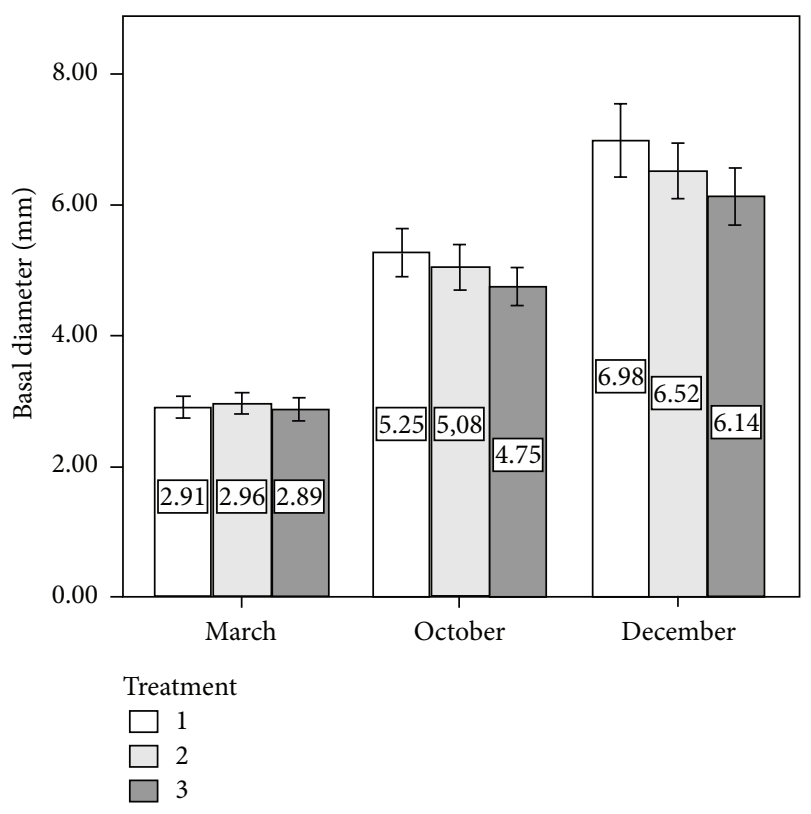

FIGURE 3: Mean basal diameters at planting date (March 2010) and after 7 months (October 2010) and 9 months (December 2010). Treatment 1: control. Treatment 2: seedlings with $120 \mathrm{~cm}$ shelters. Treatment 3: seedlings with $150 \mathrm{~cm}$ shelters.

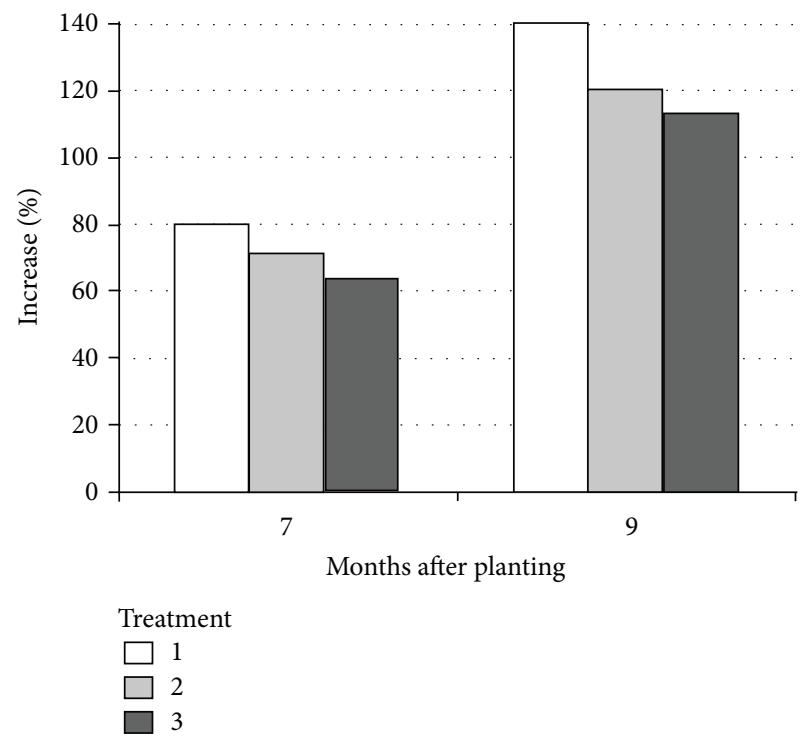

FIGURE 4: Increases of basal diameters for the argan tree seedlings. Treatment 1: control. Treatment 2: seedlings with $120 \mathrm{~cm}$ shelters. Treatment 3: seedlings with $150 \mathrm{~cm}$ shelters.

with those found for several tree species [14-16] and also for Argania spinosa under nonlimiting conditions [39].

3.4. Height to Diameter (H/D) Ratio. The results showed a highly significant effect of treatments on the $H / D$ ratio $(P<$ 0.001) both for October and December 2010.

The height to diameter ratio ( $H / D$ ratio) is an important factor, which describes the type of stem that each tree develops [40]. A lower ratio means a more vigorous tree [39]. 
TABLE 3: $H / D$ ratio mean of argan seedlings for October and December 2010. Values sharing the same letter within the same date are not significantly different at $5 \%$ by Scheffé test.

\begin{tabular}{lccc}
\hline Date & Treatment & Mean & SD \\
\hline \multirow{3}{*}{ October 2010 } & Control & $56.31^{\mathrm{a}}$ & 14.17 \\
& T120 & $72.82^{\mathrm{b}}$ & 16.06 \\
& T150 & $72.96^{\mathrm{b}}$ & 21.16 \\
\hline \multirow{3}{*}{ December 2010 } & Control & $47.88^{\mathrm{a}}$ & 12.42 \\
& T120 & $66.68^{\mathrm{b}}$ & 16.36 \\
& T150 & $66.82^{\mathrm{b}}$ & 21.96 \\
\hline
\end{tabular}

At seven months as well as nine months, the $H / D$ ratio of the control was statistically much lower than that for the sheltered trees (Table 3).

A low $H / D$ ratio is the sign of a stable tree with vigorous and powerful roots [40]. It has also been reported that shelter promotes rapid and vigorous root growth immediately after planting for Quercus ilex and Pinus halepensis seedlings under nonlimiting water availability conditions in Mediterranean climate [41].

On the other hand, the height to diameter ratio decreased with the length of the tube, but with no significant difference. These results show that $H / D$ ratio has decreased between October and December. This decrease generally results in more vigorous trees. These results confirm those found for argan trees under nonlimiting water conditions [39], where the $H / D$ ratio had a value of 53 for the control versus 74 to 104 for the sheltered trees depending on the type of shelter.

\section{Conclusions}

Two years after planting, the results have shown the beneficial effect of shelters on the survival rate of argan seedlings with a gain of $26 \%$.

Tree shelters have, also, stimulated the height growth of the argan trees. Thus, the argan seedlings began to emerge from their shelters one year after planting. Seven months after planting, growing height showed a gain of $28 \%$ and $64 \%$, respectively, for the first and second year for sheltered trees $(120 \mathrm{~cm})$. This result is very important as it may reduce the duration of deferred grazing. Diameter growth basal was not significantly affected by the introduction of tree shelters. Tree shelters $(120 \mathrm{~cm})$ induced a ratio $H / D$ 69\% higher compared to the control but which can still be considered acceptable.

Survival rate is the decisive parameter for the success or failure of a regeneration project. The use of tree shelter showed survival rates of $94 \%$ after two years. This can be considered exceptional on harsh conditions in southwestern Morocco with irregular rainfall and extreme summer temperatures that sometimes exceeded $48^{\circ} \mathrm{C}$. The use of tree shelters should be considered one of the most effective ecotechnological treatments to enhance both seedling survival and growth [23].

With regard to the height of tree shelters, the results showed no significant differences for the studied parameters. Therefore, the use of $120 \mathrm{~cm}$ tree shelters would be suitable since it would allow a faster emergence of the plants from their shelters and a better $H / D$ ratio.

This study is one of the first field trials with Argania spinosa in its natural distribution area. Two growing seasons after planting, tree shelter, designed initially to protect against browsing, could enhance the establishment and growth of argan trees planted on harsh conditions in southwestern Morocco.

\section{Conflict of Interests}

The authors declare that there is no conflict of interests regarding the publication of this paper.

\section{Acknowledgments}

The authors would like to thank the Forestry Research Center (CRF) who supported this study. The authors are grateful to the Regional Department of Water and Forests (DREFLCDSO) and their staff for their assistance in all phases of this research, including seedling supply and plantation installation. Special thanks are given to Tubex for providing tree shelters.

\section{References}

[1] Haut Commissariat aux Eaux et Forêts et à la Lutte Contre la Désertification, "Les formations forestières," HCEFLCD, 1996, http://www.eauxetforets.gov.ma/fr/text.aspx?id=1062\&uid=75.

[2] L. Kenny, "Histoire de l'arganier," in Atlas de l'Arganier et de l'Arganeraie, L. Kenny and I. De Zborowski, Eds., pp. 12-38, Institut Agronomique et Vétérinaire Hassan II, Rabat, Morocco, 2007.

[3] A. Benabid, "Biodiversité écosystémique et paysagère," in Flore et écosystèmes du Maroc: Evaluation et Préservation de la Biodiversité, A. Benabid, Ed., pp. 225-286, Ibis Press, Paris, France, 2000.

[4] F. Msanda, A. El Aboudi, and J. P. Peltier, "Biodiversité et biogéographie de l'arganeraie marocaine," Cahiers Agricultures, vol. 14, no. 4, pp. 357-364, 2005.

[5] P. Boudy, "Monographie et traitement de l'arganier," in Economie Forestière Nord-Africaine Tome deuxième, P. Boudy, Ed., pp. 382-416, Larose, Paris, France, 1950.

[6] Food and Agriculture Organization of the United Nations, Evaluation des Ressources Forestieres Mondiales 2010: Rapport National-Maroc, FAO, 2010, http://www.fao.org/docrep/013/ al574F/al574f.pdf.

[7] H. Faouzi and J. Martin, "Soutenabilité de l'arganeraie marocaine," Confins, vol. 20, 2014, http://confins.revues.org/8842.

[8] C. Defaa, A. Achour, A. Hossayni, R. Bellefontaine, A. El Mousadik, and F. Msanda, "Analyse de l'itinéraire technique d'un périmètre exceptionnellement réussi de régénération d’arganier," in Actes du ler Congrès International sur l'Arganier, pp. 83-92, Institut National de la Recherche Agronomique, Agadir, Morocco, December 2013.

[9] G. Tuley, "The growth of young oak trees in shelters," Forestry, vol. 58, no. 2, pp. 181-195, 1985.

[10] G. Armand, "Techniques de protection contre les cervidés," Revue Forestière Française, vol. 44, pp. 99-103, 1992. 
[11] J. H. McAdam, "An evaluation of tree protection methods against Scottish Blackface sheep in an upland agroforestry system," Forest Ecology and Management, vol. 45, no. 1-4, pp. 119-125, 1991.

[12] D. Gautier, T. Tapsou, and D. Christian, "Quand l'éleveur élève aussi...des arbres. Un essai de protection avec des manchons de jeunes arbres en milieu soudano-sahélien fortement pâturé," in Savanes Africaines: Des Espaces en Mutation, des Acteurs Face à de Nouveaux Défis, pp. 27-31, Cirad, Cirad, Montpellier, France, 2007.

[13] J. C. Arnold and S. M. Alston, "Life cycle assessment of the production and use of polypropylene tree shelters," Journal of Environmental Management, vol. 94, no. 1, pp. 1-12, 2012.

[14] C. Dupraz, "Les protections de plants à effet de serre: ce qu'en pensent les arbres," Revue Forestière Française, vol. 49, pp. 417432, 1997.

[15] D. W. Burger, G. W. Forister, and R. Gross, "Short and longterm effects of tree shelters on the root and stem growth of ornamental trees," Journal of Arboriculture, vol. 23, no. 2, pp. 49-56, 1997.

[16] M. N. Jiménez, F. B. Navarro, M. Á. Ripoll, I. Bocio, and E. De Simón, "Effect of shelter tubes on establishment and growth of Juniperus thurifera L. (Cupressaceae) seedlings in Mediterranean semi-arid environment," Annals of Forest Science, vol. 62, no. 7, pp. 717-725, 2005.

[17] H. Scheffé, "A method for judging all contrasts in the analysis of variance," Biometrika, vol. 40, pp. 87-104, 1953.

[18] P. Dagnelie, "Inférence statistique à une et à deux dimensions," in Statistique Théorique et Appliquée Tome 2, P. Dagnelie, Ed., De Boeck, Brussels, Belgium, 2011.

[19] J. D. Bakker, L. B. Colasurdo, and J. R. Evans, "Enhancing Garry oak seedling performance in a semiarid environment," Northwest Science, vol. 86, no. 4, pp. 300-309, 2012.

[20] J. G. Pausas, C. Bladé, A. Valdecantos et al., "Pines and oaks in the restoration of Mediterranean landscapes of Spain: new perspectives for an old practice-a review," Plant Ecology, vol. 171, no. 1-2, pp. 209-220, 2004.

[21] H. Chaar, T. Mechergui, A. Khouaja, and H. Abid, "Effects of treeshelters and polyethylene mulch sheets on survival and growth of cork oak (Quercus suber L.) seedlings planted in northwestern Tunisia," Forest Ecology and Management, vol. 256, no. 4, pp. 722-731, 2008.

[22] F. M. Padilla, J. D. D. Miranda, R. Ortega, M. Hervás, J. Sánchez, and F. I. Pugnaire, "Does shelter enhance early seedling survival in dry environments? A test with eight Mediterranean species," Applied Vegetation Science, vol. 14, no. 1, pp. 31-39, 2011.

[23] J. Piñeiro, F. T. Maestre, L. Bartolomé, and A. Valdecantos, "Ecotechnology as a tool for restoring degraded drylands: a meta-analysis of field experiments," Ecological Engineering, vol. 61, pp. 133-144, 2013.

[24] C. Ceacero, R. Navarro-Cerrillo, J. Díaz-Hernández, and A. Del Campo, "Is tree shelter protection an effective complement to weed competition management in improving the morphophysiological response of holm oak planted seedlings?" iForest, vol. 7, no. 5, pp. 289-299, 2014.

[25] A. M. Stiffarm, Phytoremediation case study [M.Phil. thesis], Kansas State University, Manhattan, Kan, USA, 2015.

[26] J. Bellot, J. M. Ortiz De Urbina, A. Bonet, and J. R. Sánchez, "The effects of treeshelters on the growth of Quercus cocciferaL. seedlings in a semiarid environment," Forestry, vol. 75, no. 1, pp. 89-106, 2002.
[27] F. Famiani, P. Proietti, M. Micheli et al., "Effects of tree shelters on young olive (Olea europaea) tree growth and physiology," New Zealand Journal of Crop and Horticultural Science, vol. 35, no. 3, pp. 303-312, 2007.

[28] J.-E. Bergez and C. Dupraz, "Transpiration rate of Prunus avium L. seedlings inside an unventilated treeshelter," Forest Ecology and Management, vol. 97, no. 3, pp. 255-264, 1997.

[29] M. F. Urretavizcaya and G. E. Defossé, "Effects of nurse shrubs and tree shelters on the survival and growth of two Austrocedrus chilensis seedling types in a forest restoration trial in semiarid Patagonia, Argentina," Annals of Forest Science, vol. 70, no. 1, pp. 21-30, 2013.

[30] G. M. Dunn, M. S. Cant, and M. R. Nester, "Potential of two tree shelters to aid the early establishment and growth of three Australian tree species on the Darling Downs, south-east Queensland," Australian Forestry, vol. 57, no. 3, pp. 95-97, 1994.

[31] T. Mechergui, B. Hasnaoui, M. Pardos, and N. Boussaidi, "Firstyear effects of tree shelters and mulching on survival and growth of zeen oak (Quercus canariensis Lamk.) seedlings planted in North-Western Tunisia," Revue D'Écologie, vol. 67, no. 1, pp. 3$18,2012$.

[32] D. De Steven, "Experiments on mechanisms of tree establishment in old-field succession: seedling survival and growth," Ecology, vol. 72, no. 3, pp. 1076-1088, 1991.

[33] A. N. Burdett, "Physiological processes in plantation establishment and the development of specifications for forest planting stock," Canadian Journal of Forest Research, vol. 20, no. 4, pp. 415-427, 1990.

[34] D. W. Burger, P. Svihra, and R. Harris, "Tree shelter use in producing container-grown trees," HortScience, vol. 27, no. 1, pp. 30-32, 1992.

[35] P. Balandier, J. L. Guitton, and H. Rapey, "Amélioration des tubes abris protégeant les jeunes arbres contre les animaux," Ingénieries, no. 4, pp. 41-48, 1995.

[36] J. A. Oliet and D. F. Jacobs, "Microclimatic conditions and plant morpho-physiological development within a tree shelter environment during establishment of Quercus ilex seedlings," Agricultural and Forest Meteorology, vol. 144, no. 1-2, pp. 58-72, 2007.

[37] T. Mechergui, M. Pardos, N. Boussaidi, B. Hasnaoui, and D. F. Jacobs, "Development of cork oak (Quercus suber L.) seedlings in response to tree shelters and mulching in northwestern Tunisia," Journal of Forestry Research, vol. 24, no. 2, pp. 193-204, 2013.

[38] F. Ponder Jr. and J. W. Van Sambeek, "Nine-year performance of four hardwoods on a harvested site with and without fertilizer tree shelters, and weed mats in Southern Illinois," in Proceedings of the 18th Central Hardwoods Forest Conference, General Technical Report GTR-NRS, pp. 63-71, US Forest Service, USDA, Newtown, Pa, USA, July 2013.

[39] M. Fallah, C. Dupraz, and M. Dauzat, "Impact des protections individuelles à effet de serre sur des plants d'arganier en conditions hydriques non limitantes," Forêt Méditerranéenne, vol. 3, pp. 235-240, 2001.

[40] J. de Champs, "Mesures sylvicoles préventives," Revue Forestière Française, vol. 4, pp. 313-322, 1987.

[41] A. V. De Castro, J. A. Oliet, J. Puértolas, and D. F. Jacobs, "Light transmissivity of tube shelters affects root growth and biomass allocation of Quercus ilex L. and Pinus halepensis Mill," Annals of Forest Science, vol. 71, no. 1, pp. 91-99, 2014. 

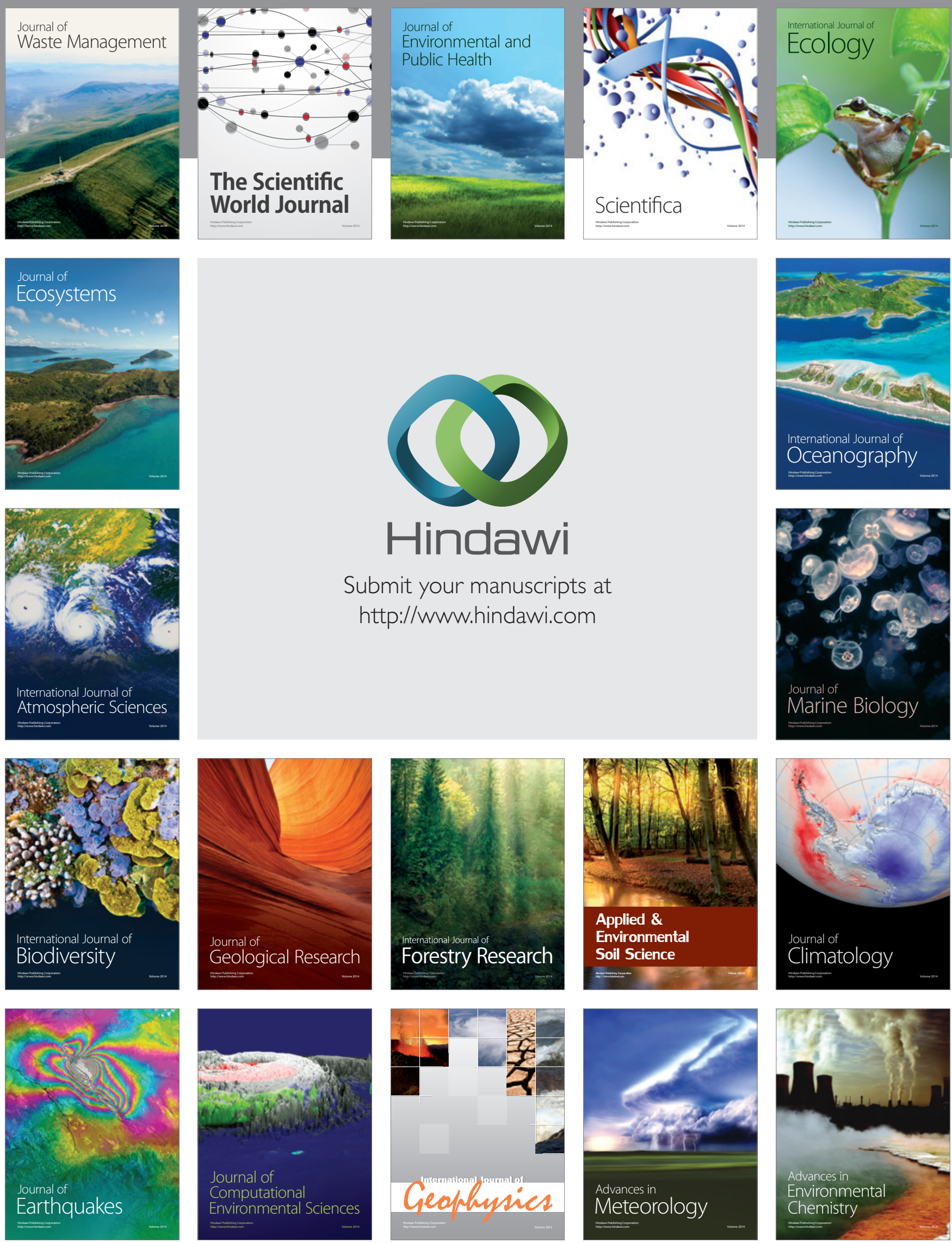